\title{
Do Youth Trust in Political News on Social Media? Impacts of Trust or Distrust on the Egyptian Young Citizens Political Engagement
}

Adel Saleh, Ph.D.*

\begin{abstract}
This study examines to what degree youth trust political news on social media as it is an important political communication platform. The study used standard attitudinal online survey questions to assess interest in politics, sources of getting political news, trusting attitudes, and online political engagement activities. The online survey was conducted on a sample of young citizens ( $n=225$, age 18 to 35 years). Findings reveal the importance of social media as a political information source for young people, however, trustworthy of political information has been discovered to be low. Youth has less trust in political information sources on social media, other citizens, and political institutions. Though, young citizens have also less trust in political news in the traditional media, surprisingly it is higher than trustworthy of social media. Mistrust attitudes predict distrusting behaviors, such as disengagement of societal or political activities as a reflection of political cynicism. Results confirm also, distrust leads to less interest to interact with other net users and a decline of social and political engagement. Trust in political news on social media alters when the public are of different age education, gender, and economic status. In addition, Regression analysis shows that trust in political information on social media is correlated to six predictor variables in the model: trust in traditional media, trust in government, trust in others, political engagement, gender, and the family economic status. These results shed a light on the need of improving the quality of online political news on social media as it seems to be a vital component of the virtual public sphere. It is plausible to assume that declining political news credibility and increasing mistrust of political news online sources confirmed by this study might negatively impact the public discourse, social capital and, potentially harm democratic transition.
\end{abstract}

Keywords: trust, youth, political news, social media, political engagement, Egypt.

* Associate Professor of Political Communication, British University in Egypt 


\section{INTRODUCTION}

In democratic societies, the media is playing a vital role to keep people well informed about the public issues. Trusted news sources is crucial for assisting citizens to effectively engage in politics depending on factbased- information. Due to the remarkable connection between news and democracy, trustfulness and credibility of news sources became a focus for various studies in political communication. Trust has long been considered one of the reasons that affect citizen's consumption of political news. Nonetheless, the increase in the level of online information, together with the availability of many online news service platforms with many interactive features, may have changed relationship between usage of political news and its trustfulness (Fletcher and Park, 2015).

Online news seekers can get preference content, make their news choices, and to compile facts from various sources. Social media supported this interactive and on demand environment, where users can also create and disseminate news that contribute to informing and educating about public affairs. This type of online deliberation might lead to forming a public discourse characterized as "alternative public sphere" or "virtual public sphere" (Dutton, 2009).

Relying on social media to get news is notably growing in Egypt because of increasing the number of internet users and the availability of access to all types of news through online platforms. As the percentage of Internet penetration either via computer or smartphone is developing, the number of Egyptians who are using social media, especially Facebook is rising steadily. Statistics show that at least 35\% of the total population (72\% of Internet users) are Facebook subscribers (Internet Users Statistics for Africa, 2018) in adding to two million users are active in Twitter (Digital Marketing Statistics \& Metrics, 2018). Meanwhile, new social media applications, such as Instagram and Snapchat attracted many of the Internet users, especially youth.

Statistics of global social networking activity indicate that there were 1.96 billion users in 2015 with estimates of 2.44 billion users in 2018 (Statista, 2015). In whole the social media platforms, Facebook, Twitter, and YouTube are among the most 10 popular ranked social media sites (Alexa, 2015). 
Worldwide, news is increasingly consumed through social media. Many researchers pointed out that there is a remarkable shift to online media as sources of news and social media is becoming an important source of news, especially for young adults (Knight Foundation, 2018).

In the Reuters Digital News Report 2017 ( $N=70,000$ from 36 markets) listed social media as the most important source of news. While it is confirmed that young people are more user for social media as a source of news, results point out that for 25-34-year-olds (21\%), 35-44-yearolds (15\%), 45-54-year-olds (10\%) and 55+ year-olds (7\%). This means that there is a large portion of the news consumers named social media among the primary resources (Newman et.al 2017).

A representative 2017 survey by the Pew Research Center $(\mathrm{N}=4,971)$ pointed out that $67 \%$ of U.S. adults get at least some of their news on social media. Most respondents point out that online news providers have positive effects for the news environment. While a majority assume the impact of the politician's use of social media as a political communication tool has been negative. (Pew Research Center, 2017).

With the expansion of depending on online user's news production, a significant notice has have been given to explore the impact of social media in the contemporary society. Political communication research has been directed to explore the extent to which this new communication tool alters ways of political news consumption, trust of this type, virtual political discourse and impact on political participation. (Snelson, 2016).

Concerning trusting media, Long-term Gallup trend data recorded a decrease in the level of trust among Americans, with 41\% in 2017 express they trust the media, down from 54\% in 2003. (Knight Foundation 2018). Although worldwide studies confirm declining in trust of news media over the time, the availability of accessing news via digital platforms has revived concerns about declining credibility and news quality, and the probability of negative impact on democracy (e.g. Silverman 2015). In this context, studies indicate that most U.S. adults consider fake news to be a very serious $(56 \%)$ or somewhat serious threat (32\%) to democracy (Knight Foundation, 2018).

It is remarkable that the networked news production and consumption have heightened uncertainty about news dissemination on social media 
which affected news industries at the international level. While it is noticeable that observations of level trusting political news on social are in some cases declining compared with traditional news media, further investigation about the impact of social media on trust in political news should be conducted in different contexts.

In the Egyptian framework, although there is a change in types of using technology in producing and distributing news compared with 2011the so-called "Arab Spring" and flourished era of using social media, people are still using social media as a source of news and a space for discussing public issues. However, data on credibility and trustworthy of this information and impacts of this on the young user's political engagement is blurred and needs further academic examinations.

Because trust is considered as a central concept for understanding important economic, social, and political behaviors. (Ben-Ner, A., Halldorsson, $F$., 2006) the current study investigates level of trust in political news on social media among youth driven by the finding that social media is the a main news source for a majority of people, especially young adults worldwide (Heuer \& Breiter, 2018). It seeks to address challenges posed by online political news consumption and understanding of how users quantify trust in social media political news and which factors influence this trust and which variables can help predicting trust in political news on social media. In addition, it examines impact of trust or distrust on political engagement in a wider conceptual framework.

\section{Research Problem:}

This study is guided by the following questions: To what extent do youth in Egypt trust political news generated and distributed via social media; which variables can predict the level of trust or distrust; and which effects of trusting or distrusting this type of news on their political engagement?

\section{Questions \& Hypotheses}

\section{Questions:}

Q1: To what extent do youth in Egypt rely on social media to obtain political news? 
Q2: For which purposes do youth rely on social media to use political news?

Q3: How much do youth trust in others and political entities?

Q4: To what extent do youth trust in political news on social media?

Q5: To what extent do youth trust in political news on social media compared with traditional media?

Q6: Does the use of social media affect the political engagement of youth in Egypt?

Q7: Which variables affect youth trust in political news on social media?

\section{Hypotheses:}

H1: There will be a significant predication of trust in political news on social media by trust in traditional media, trust in government performance, trust in others, political engagement, gender, and the family economic status.

$\mathrm{H} 2 \mathrm{a}$ : In the presence of others, there will be a significant prediction of trust in political news on social media by trust in traditional media.

$\mathrm{H} 2 \mathrm{~b}$ : In the presence of others, there will be a significant prediction of trust in political news on social media by trust in government performance.

$\mathrm{H} 2 \mathrm{c}$ : In the presence of others, there will be a significant prediction of trust in political news on social media by trust in others.

$\mathrm{H} 2 \mathrm{~d}$ : In the presence of others, there will be a significant prediction of trust in political news on social media by political engagement.

$\mathrm{H} 2 \mathrm{e}$ : In the presence of others, there will be a significant prediction of trust in political news on social media by gender.

H2f: In the presence of others, there will be a significant prediction of trust in political news on social media by the family economic status.

\section{Contextual Framework \& Literature Review}

The concept of trust is viewed as one of the essential building blocks of social science theory. It has been researched across a variety of 
disciplines and has even been linked with the broader conception of social capital (Bauer \& Freitag 2018).

Generally, trust is identified as a belief or expectation about people, institutions, etc., or as intended behaviors or willingness to rely on another party. As consequence, if trust is violated in a party, there as a possibility negative impact (e.g. Mayer et al.1995).

The measurement of trust requires a clear concept of trust. Some scholars see that the term "trust" first and foremost indicates an expectation and not a behavior (e.g., Hardin 2002). Consequently, some researchers recommend calling it "trusting behavior" or "behaviorally exhibited trust" (Barr 2003; Fehr et al. 2002). Definitions of trust focus on a confident, positive expectation, and a willingness to rely upon (Rousseau et al. 1998).

Indeed, it is agreed that looking at trust as a process rather than one step will help in overcoming many conceptual and definitional issues. This perspective deals with trust as a process that encompasses multiple "trusting" concepts (e.g., trusting dispositions, attitudes, beliefs, expectations, intentions, choices, behaviors, etc.) (Pytlik Zillig \&Kimbrough, 2015).

Moreover, trust is situation-specific. Such situations can be described by using a few parameters (Sztompka1999, 55). When deliberating over trust, researchers essentially speak about a truster A that trusts (judges the trustworthiness of) a trustee $\mathrm{B}$ with regard to some behavior $\mathrm{X}$ in context $\mathrm{Y}$ at time t. Adding time t clarifies that trust may change, that is, a truster may adjust his expectations over time (Bauer \& Freitag, 2018).

The trust literature, social network, and social capital theory point out that the online social networks technological structure and operational process are running in a context of trust. (Grabner-Kräuter and Bitter, 2015)

With regards to media, trust can be viewed as a main element, complemented by other professional values such as, accuracy, fairness, telling the whole story, being unbiased, and balance (West 1994; Thorson et al. 2010). In the media trust literature, the news media is the frame through which people get exposed to the national and 
international affairs. Abundant of findings show out trust in the media is low and declining, though giving the fact that there is no specific measurement of media trustfulness meanings. Scholars argue that distrust in the media happens when the news does not reflect realities as recognized by the public (Coleman and his colleagues, 2009). Kohring and Matthes, 2007 propose four dimensions of trust measurement: trust in the reported topics selectivity, information selectivity, Journalists framing of the information, and in the accuracy.

Scholars addressed various factors that could affect assessments of news trustworthiness. (Lee, 2010) noticed that trust in the news media was influenced by user's political ideology, trust in government institutions, and economic views. Other scholars highlight media exposure and media dependence, as well as individual characteristics as complementary factors that probably affect level of trust in media news (Golan, 2010). While others illustrate interpersonal variables appear especially necessary in measuring media bias and level of trust in political news (Eveland and Shah, 2003)

Another study concludes that differences in selected media trustfulness predictors across national sub-samples show a significant role of the national context along with socioeconomic and cultural lines. (Macek et al. 2017)

Relevant literature points out that credibility has frequently been used as a milestone of trust: Predictably, people who see the media to be credible seem more likely to depend on media as a source of news than those who do not (Wanta and Hu 1994), even though concluding that the relationship is not inevitably a strong one (Kouisis 2009). Previous studies have pointed out that trust in the news media affects how citizens consume news. People trust traditional mor than other types of news providers (Tsfati and Cappella 2003). At the same time, surprisingly, relevant research show that level of trust is not the only factor that affect news, and people consume news from sources even they do not trust (Tsfati and Cappella 2005).

Within a fragmented news environment concerned by charges of less quality and losing the journalistic norms of social media news which lead to the phenomena of 'fake news', universal concern about trust in the media has stepped out from industry and academic spheres to 
mainstream discourse. In many countries, people express declining levels of trust in a variety of civic bodies but particularly in the media (Edelman Trust Barometer 2018).

A new comparative trend of online and traditional information credibility raised up due to the wide use of online platforms in creating and disseminating news (Flanagin and Metzger 2007). Numerous of studies have examined the perceived credibility of online information sources, specially social media, such as (Johnson and Kaye 2014 ; Westerman, Spence and van der Heide 2014; Clerwell 2014).

Initially, some studies concluded that audiences use alternative media because they feel less trust in professional media - or as Yariv Tsfati puts it, "[w] hen they mistrust the media, they seek alternatives" (Tsfati, 2010). This signify that trust in alternative media is connected with mistrust of traditional media. In contrast, it has been suggested that trust in alternative and professional media are not connected and that differences of their survive indicate distinct types of expectations predicted by online media (Macková et al., 2017).

Moreover, researchers assume that trust in alternative media is - similar to general trust in media- could be predicable by investigating user's political attitudes and the national context (Tsfati and Ariely, 2014).

In a pioneering comparative study, (Tsfati and Cappella, 2003) distinguished between traditional and non-traditional news sources and discovered that media skepticism was correlated with online news consumption. Their differentiation between both news sources was basically based on the variations of access method, content, performance, and user's engagement.

From a survey of 1,000 students of institutions of higher education in Malaysia, Wilson et al., 2011 fund that youth depend on traditional media to get news. However, traditional media are not able to offer satisfactory information for young people, so they are looking for supplementary information from online news sources. However, their level of trust in online news platforms is grounded on how precisely these websites reflect the public affairs. Also, results also show that students believe that online news sources present diverse viewpoints, are more critical, have more in-depth analysis, and are relatively free. Apparently, these reasons influence positively on the level of trust in 
the online news sources among young people. Surprisingly, the trust extends to online news sources but excludes blogs. However, results showed that youth are still relying on traditional media to get news.

A study in China explores the level of trust users have on news getting from social media versus traditional media. This large-scale anonymous survey showed that traditional and online news attract different audience segments and each group uses various features to assess news trustworthiness. The results suggest that in controlled news environments, online media has the potential to replace traditional news channels. (Wang \& Mark, 2013).

(Tsfati and Ariely 2014) compared trust across 44 countries and found that political interest, interpersonal trust, and exposure to television news and newspapers were positively correlated with trust in media. While they found that there is a negative correlation between education and exposure to online news.

Seckler et al 2015 examined what website characteristics increase trust or cause distrust. They studied how to design elements that can be used to enhance trust or to prevent distrust. This prompted the research questions whether users distinguish news sources by their trust ratings and whether social navigation features like Facebook likes, comments, and shares influence level of trust ratings. Findings from $N=221$ participants suggest that distrust is mostly an effect of graphical and structural design issues of a website, while trust is grounded on social factors such as reviews or recommendations by friends.

Ceron, 2015 study investigated the correlation between online information usage and political trust. It used a cross-sectional analysis of Eurobarometer survey data related to 27 countries. Findings pointed out that people are trusting more information and news gained from websites than these available on social media. This reflected on the discussion one the role of social media inputs in the virtual public sphere, along with the debate on the level of professionalism of citizen journalism.

In the study of Heuer \& Breiter, 2018, users have been asked to assess their trust in news items. Researchers investigate influence that social navigation features like the number of Facebook likes, comments, and shares have on the trustworthiness ratings of news. To understand trust 
in social media news, a study with 108 German high-school students who provided trust ratings for online news including quality media and fake news. Findings showed that the mean trust rating of a participants can be predicted from their interpersonal trust.

Flintham et al 2018 study of social media news consumption analyzed whether trust can be measured, how generalized beliefs on interpersonal trust interact with trust, and how such generalized beliefs can be used to address those likely to false trust and false distrust. Findings show that two-thirds of respondents regularly use news via Facebook and that one third had at some point come across fake news that they initially believed to be true.

Surveys conducted by the Brazilian government have also addressed levels of trust in news across multiple platforms. Findings indicate lower levels of overall trust than concluded by the international studies, with a common trend of distrust of online media. Respondents raised concerns about the lack of online controls, leading to low-quality content that affects negatively its credibility (Milhorance and Singer 2018).

The annual Digital News Report Australia (Fisher, Park, Lee, Fuller, \& Sang, 2019; Park, Fisher, Fuller, \& Lee, 2018) results consistently shows people who mainly depend on traditional media tend to trust news more than those who primarily use social media and. In addition, findings point out that the level of trust is significantly associated with socio-demographic and attitudinal variables.

Another study in 2019 examined the factors that lead users to trust news on social media. Study reveals two factors that might be influence the assessment of news on social media: (1) the trustworthiness of the source of sharing the content; (2) the credibility of the media outlet producing the content (Sterrett et al., 2019). (Norris 2000) suggests that there is a significant post correlation between using online political information provided by online sources and level of trust, conditioned with political interest. Some other researchers point out that seeking for online political information seems uncorrelated with trust in government (Kaye \& Johnson, 2002). Also, Avery (2009) does not find a correlation between gaining online political information and trust in government. 
McNeal et al. (2008) concludes that seeking for online information has a positive, but not significant, effect on political trust. Norris (2011) reveals that it is associated with less democratic satisfaction, while Im et al. (2014) show that users who spend more time online express a lower degree of trust in government.

Trusting in political information that the young citizens do gain, is an important factor that affects their engagement and capitalizing their social networks. In other words, political communication researchers are interested in investigating the young generation's patterns of using political information sources, level of trusting these sources, and reflections of consuming political information on societal and political engagement. More broadly, Tsfati and Cappella, 2003) define trust as a consequential phenomenon: Trust leads to a greater probability of cooperative engagement, while mistrust reduces that possibility. On the other hand, research on trust and social capital has shown that using social media might be enhance social trust and social networks (Ellison et al., 2007).

The impact of trusting in political information on engagement and political participation is another area that needs to be explored as it is relevant to identify the role of online media in enhancing democracy. In this regard, it is important to highlight that the conceptions of engagement and participation are sometimes treated as almost synonymous. (Boulianne, 2009) does not differentiate between them and defines political engagement broadly as behaviors that associate directly to political institutions and the work of political organizations. Nevertheless, (Hargittai \& Shaw, 2013, Holt at al., 2013) see that political engagement is tackled as a broader concept which includes public sphere deliberation, political expression, and political participation.

The Internet potential impact on altering the nature of political engagement, or how trust in the online news might influence the youth participatory behavior, has been a subject of massive debate for the last two decades (Suminas \& Mierzecka, 2014). However, few studies focus on exploring the relationship between offline and online news consumption and political engagement from a comparative perspective (Fletcher and Park, 2015). 
Empirically, there is no robust conclusion on a causal relationship between types of media use and political engagement (Boulianne, 2011). Within the area of online media consumption and political engagement research, four main models have outlined: 1) the Internet impact is correlated to the declining of political engagement; 2) the internet has no significant impact on political engagement either positively or negatively; 3) the Internet impact is linked with maintaining or reinforcing political activism intentions ; 4) the Internet impact is positively correlated with increasing channels of political engagements.

Theoretically, researchers argue that interacting with social nets members in the virtual sphere may open more opportunities to get political information that could predict improving political knowledge of social users. Fletcher \& Nielsen, 2018 suggest that incidental exposure to different information channels may increase the possibility of knowledgeable outcomes beginning with making note of an interesting fact of user comment to clicking on news hyperlinks and engaging in close reading and cognitive elaboration (Fletcher \& Nielsen, 2018). However, exploring some variables might be especially important in related exposure and engagement scenarios. Among these variables, some studies focus on two aspects of political engagement interest and participation, including new forms of Internet activism in correlation to information behaviors.

(Boulianne, 2011) pointed out that use of online news media had a positive causal impact on political interest. Findings from a panel data, showing that relying on online news sources could create political interest and lead to political participation for citizen who are not engaged, compared with those who are currently engaged. (Dimitrova et al., 2011) concluded that the use of political party online platforms for political purposes had a causal impact on offline political participation.

(Vissers \& Stolle, 2013) look at political participation as all behavioral components of political engagement in which citizens express their political viewpoints and/or communicate their opinion to political decision-makers, encompassing the online activities. 
Holt and others examine how media use varies across age groups- and whether this be relevant for people's tendency to participate in politics. In other words, the study explores the impact of social media and traditional media use for political purposes on political interest and offline political participation. Findings show obvious variations in media use between age groups. Also, it points out that use of political social media and interest in political news on traditional media enhance political engagement over a period. This four-wave panel study indicates that regular social media use during political campaigning can motivate political participation among youth (Holt at al., 2013).

(Fletcher and Park, 2015) investigate across eleven states the impact of individual trust in the news media on source favorites and online participatory behaviors, such as sharing and commenting on online news. Findings show that those with lack of trust be likely to favor alternative news media sources like social media and are more probably engage in numerous forms of online news participation. These correlations tend to be strongest in Northern European countries but are weaker in other regions. Exploring alternative opinions and seeking to verify news credibility may possibly be among the rationales at the back of these associations.

Another relevant study shows that news consumption is correlated with users' general online activities, especially with young people who tend to use social media for gaining news and doing social actions as well. Some evidence suggests that verifications of news to make certain of information credibility, influences how online political news seekers behave online (Stroud et al., 2016).

\section{METHODOLOGY}

\section{Sample and Survey:}

The study uses a sample of 225 participants. Most participants were female $(65.3 \%)$, have university qualification $(76 \%)$, young adults age $18-24$ years $(71 \%)$, and with moderate family income $(60 \%)$. The study procedure consisted of an online survey as a quantitative method conducted on 17-30 July 2019. Respondents fill out an online anonymous 18-item questionnaire, which typically takes 7 to 10 minutes. The Sample was non-random sample have been reached via the internet. It was an available purposive sample due to difficulty in 
reaching the list of the social media users in Egypt. The online survey provides anonymous space for respondents to answer freely.

The survey encompasses four sections. The first section investigates youth interest in politics and political news sources that they rely on to get information about public issues.

The second section contains trust questions. The trust questions derived a wide range of attitudinal questions of trust studies by different researchers (e.g. Glaeser et al., 2000; Bauer and Freitag, 2018). Based on previous studies, the author designed numerous trust questions of his own. Scale for measuring general trust (i.e. interpersonal trust, trust in others, trust in the government) comprises nine items. The scale for measuring trust in political news in social media comprises six items. The final scores were computed with averaged items.

The third section of the survey includes behavioral questions to measure youth interactivity with social media political news, societal, and political engagement. While the fourth part contains socio-demographic questions (e.g., gender, education, age and, family income).

\section{Measures:}

The study combines two constructs to measure trust in general and trust in political news sources, in specifically. First, nine trust indicators for generalized trust (Faith- in- people, interpersonal trust, and institutional trust) (cf. Table 5). Second, six trust indicators for online political news sources (cf. Table 6). Cronbach's Alpha of the general trust (interpersonal trust/trust in others/trust in the government) scale (9 items) is .58, while Cronbach's Alpha of the social media trust scale (6 items) is .60 for our sample $(\mathrm{N}=225)$.

The dependent variable trust in political news on social media was scaled through a spectrum of six items ranging from "strongly disagree" (1) to "strongly agree" (5). Answers were sorted into a categorical variable, with answers which indicated agreement with positive statement ranked as having high or very high trust in the news media, while answers which indicated disagreement ranked as having low or very low trust and vice-versa. Those who indicated neither agree nor disagree were among users with moderate trust in the news. 
The independent variables were recorded as follows:

Trust in traditional media ("How confident are you in political news on social media compared to traditional media") was documented through a scale ranging from "low confidence" (1) to "high confidence" (5).

Trust in government, trust in others were documented through a scale of nine items ranging from "strongly disagree" (1) to "strongly agree" (5).

Political engagement, answers were provided on a five-point scale, and included (1) low interaction (5) high interaction)

To record online news participation, interviewees were asked during the last week in which of the following ways do you share or participate in news coverage? Respondents were able to select all that applied from (1) share a news story via a social network or email, (2) comment on online news story, (3) rate, like a news story, (4) others.

This study adopts a comprehensive conceptual framework for political engagement. It includes exposure to political news in any of the communication platforms, show interest in political discourse either by online interaction or offline deliberation with other about public issues. In addition, one important part of political engagement is to participate in any real political actions aim at affecting the political system.

Several other variables from the survey were encompassed in the analysis. These were age, gender, education, and family economic status and were treated as categorical. Design benefited from (Macek et.al. 2017; Fletcher and Park 2015).

\section{Data Collection and Analysis:}

Data of the conducted online survey collected using online survey software that helps to create and run professional surveys. The SPSS program has been used for analyzing data and running statistical tests to answer the questions and test the hypotheses.

For testing hypothesis 1, this study uses Multiple Regression analysis to investigate the relationship between dependent variable trust in political news on social media and other independent variables. In addition, this analysis helps to model the relationship between variables, which enables the researcher to produce predictions about 
what one variable will act based on the records of some other variables. The model consists of the predictor variables, in this case, the six predictor variables in the model are: trust in traditional media, trust in government, trust in others, political engagement, gender, and the family economic status: to predict the outcome variable (trust in political news on social media).

For testing hypothesis 2, while the ANOVA table (used in H1) shows whether the overall model is a significant predictor of the outcome variable, Coefficients table figures out the extent to which the individual predictor variables contribute to the model.

Through looking at two sections of the Coefficients table, researcher seeks to interpret the multiple regression. The first part of the table is the Sig column which shows whether the predictors significantly contributed to the model or not. The next column contains the unstandardized beta coefficients for the model (the B values). These values measure the relationships between the outcome and predictor variables. As the values are positive, so are the relationships and visversa. In addition, these $B$ values interpret the influence of each predictor has on the outcome with the continuation of the other variables' effects.

\section{RESULTS}

RQ1: To what extent do youth in Egypt depend on social media to get political news?

\section{Table 1: Sources of political information for young citizens}

\begin{tabular}{|l|l|l|}
\hline Medium & F & $\%$ \\
\hline Newspapers (Print/online) & 34 & 11 \\
\hline Radio & 32 & 10 \\
\hline TV & 91 & 27 \\
\hline Social media (Facebook \& Twitter) & 163 & 49 \\
\hline $\begin{array}{l}\text { Others (Friends, Relatives, Websites, } \\
\text { etc. }\end{array}$ & 12 & 3 \\
\hline Total & 332 & 100 \\
\hline
\end{tabular}

Source: Data are from the author's survey.

$\mathrm{N}=332$ responses (Multi responses)

Q: Which sources do you prefer to get news related to public affairs? 
Results show that the way young people gain political information has changed since different news providers have emerged on a large scale. Finding emphasis that social media are the main source of political news for youth. The study reveals that almost half of respondents rely on social media to get informed about public issues, while $27 \%$ depend on TV, $11 \%$ Newspapers, and $10 \%$ rely on Radio. This result is aligned with other findings of studies that were conducted in different global contexts confirm that depending on social media for gaining political news is growing, especially among youth.

\section{Table 2: Social media usage intensity to gain political news}

\begin{tabular}{|l|l|l|}
\hline Frequency & F & $\%$ \\
\hline At intervals more than a week & 52 & 23.1 \\
\hline Once a week & 17 & 7.6 \\
\hline Two to three times a week & 31 & 13.8 \\
\hline At least once a day & 48 & 21.3 \\
\hline More than once a day & 77 & 34.2 \\
\hline Total & 225 & 100 \\
\hline
\end{tabular}

Source: Data are from the author's survey.

$\mathrm{N}=225$

Q: How often do you use social media to get political news?

The study points out that for many respondents, social media is part of their daily routine to obtain political news. Roughly six-in-ten rely on these social networking sites more than once or once a day in following up the public issues. Once again, the study confirms that the youth are depending widely on social media as the main source for getting political news.

Table 3: Time length youth browsing political news on social media

\begin{tabular}{|l|l|l|}
\hline Period & F & $\%$ \\
\hline Less than one hour & 169 & 75.1 \\
\hline $\begin{array}{l}\text { From one hour to less than three } \\
\text { hours }\end{array}$ & 40 & 17.8 \\
\hline More than three hours & 16 & 7.1 \\
\hline Total & 225 & 100 \\
\hline
\end{tabular}

Source: Data are from the author's survey.

$\mathrm{N}=225$ 
Q: How many hours do you spend browsing social media to search for political news?

The study discovers that more than three-quarters of respondents are spending less than one hour daily to follow political news on social media, while $25 \%$ are spending more than one hour. My supposition concerning this fact is that probably young people are using social media aside by other activities and they cannot stay browsing for a long time. Moreover, this fact could be attributed to the social media characteristics as a "Fast food communication platform" where users are looking for breaking news that did not require a long time of exposure.

RQ2: For which purposes do youth depend on social media to get political news?

\section{Table 4: Purposes of preferred social media to gain political news}

\begin{tabular}{|l|l|l|}
\hline Reason & F & $\%$ \\
\hline Quick and timely in the transmission of information and news & 143 & 26 \\
\hline $\begin{array}{l}\text { Provides a broader scope for freedom of opinion and presents different } \\
\text { point of views }\end{array}$ & 129 & 24 \\
\hline $\begin{array}{l}\text { Characterized by the availability of interactive feature with the } \\
\text { information provided during it }\end{array}$ & 64 & 12 \\
\hline Is a reliable and credible source & 17 & 3 \\
\hline Characterized by flexibility and ease of use & 112 & 21 \\
\hline Provides more in-depth information & 33 & 6 \\
\hline My friends use it & 22 & 4 \\
\hline My family members use it & 15 & 3 \\
\hline Other & 4 & 1 \\
\hline Total & 539 & 100 \\
\hline
\end{tabular}

Source: Data are from the author's survey.

$\mathrm{N}=539$ responses (Multi responses)

Q: Why do you use social media to get news about public affairs (political news)? (You can choose more than one alternative)

The study highlights that the majority of young people state that they are using social media to get political news because they can get news faster compared to other media as it provides quicker and timely information and news. In addition, they pointed out the availability of interaction and easiness the content of social media. Those results support the above mentioned findings of this study which referred to that youth are not spending more time in each visit to browse political news. Results show that $26 \%$ of responses use social media to get 
political news because it is quicker than others and $21 \%$ justify relying on social media to obtain political news with ease of access to the news on social media.

Moreover, social media provide a variety of point of views as news is gathered from different sources as stated by a high ratio of users. Results show that $24 \%$ are depending on social media to obtain political news due to the availability of various point of views about raised issues.

However, few respondents identified that reason for gaining political news from social media is affiliated with the credibility or quality of political information provided in social media, only $3 \%$ of total responses.

RQ3: How much do youth trust in others and political entities (government)?

\section{Table 5: Youth general trust}

\begin{tabular}{|c|c|c|c|c|c|c|c|}
\hline Statement/phrase & $\begin{array}{l}\text { Strongly } \\
\text { Agree }\end{array}$ & Agree & $\begin{array}{l}\text { Neither } \\
\text { Agree } \\
\text { nor } \\
\text { Disagree }\end{array}$ & Disagree & $\begin{array}{l}\text { Strongly } \\
\text { Disagree }\end{array}$ & Mean & $\begin{array}{l}\text { Std. } \\
\text { Deviation }\end{array}$ \\
\hline $\begin{array}{l}\text { You can't be very } \\
\text { careful about people }\end{array}$ & $7.1 \%$ & $23.1 \%$ & $27.6 \%$ & $32.9 \%$ & $9.3 \%$ & 2.86 & 1.097 \\
\hline $\begin{array}{l}\text { If you don't pay } \\
\text { attention r to } \\
\text { yourself, people } \\
\text { will take advantage } \\
\text { of you }\end{array}$ & $39.6 \%$ & $48 \%$ & $9.3 \%$ & $2.2 \%$ & $.9 \%$ & 4.23 & .779 \\
\hline 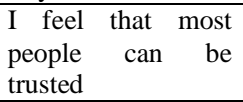 & $2.7 \%$ & $15.1 \%$ & $29.3 \%$ & $44.9 \%$ & $8 \%$ & 2.60 & .931 \\
\hline $\begin{array}{l}\text { I'm full of doubts } \\
\text { about things }\end{array}$ & $14.7 \%$ & $32.4 \%$ & $35.1 \%$ & $14.2 \%$ & $3.6 \%$ & 3.40 & 1.018 \\
\hline $\begin{array}{l}\text { I think people rarely } \\
\text { tell you the whole } \\
\text { story }\end{array}$ & $36.9 \%$ & $40.4 \%$ & $16.4 \%$ & $4.4 \%$ & $1.8 \%$ & 4.6 & .933 \\
\hline $\begin{array}{l}\text { I avoid contacts } \\
\text { with others }\end{array}$ & $4 \%$ & $21.8 \%$ & $29.3 \%$ & $34.2 \%$ & $10.7 \%$ & 2.74 & 1.042 \\
\hline $\begin{array}{l}\text { I am sure that the } \\
\text { government is } \\
\text { doing the right thing }\end{array}$ & $3.1 \%$ & $11.6 \%$ & $36 \%$ & $28.4 \%$ & $20.9 \%$ & 2.48 & 1.044 \\
\hline $\begin{array}{l}\text { The government } \\
\text { does not respond to } \\
\text { people's aspirations } \\
\text { and does not meet } \\
\text { their needs }\end{array}$ & $21.8 \%$ & $23.6 \%$ & $37.3 \%$ & $13.3 \%$ & $4 \%$ & 3.46 & 1.094 \\
\hline $\begin{array}{l}\text { The government } \\
\text { deals with the } \\
\text { economy and } \\
\text { responds to the most } \\
\text { important problems }\end{array}$ & $5.3 \%$ & $16 \%$ & $33.8 \%$ & $29.3 \%$ & $15.6 \%$ & 2.66 & 1.86 \\
\hline
\end{tabular}

Source: Data are from the author's survey.

$\mathrm{N}=225$ 
Q: You have a set of statements related to trust in general, please specify whether you agree or disagree with each statement

The study finds that young people are slightly sceptic and have less trust in others. Moreover, they have less trust in the political institutions as respondents disagree widely with positive statements describing government performance compared to negative statements. Statistics point out that the average of the six statements which scale (trust/distrust) in other citizens is tending to confirm the negative views of young people towards their counterparts. At the same time, data shows similar attitudes when young people have been asked to scale their opinion about the government through the last three statements of the opinion scale.

Based on these results which confirm that this sample of social media users have generic mistrust, it is not anticipated that this group of citizens is expected to participate effectively in any type of community participation as they do not trust other citizens and have negative views towards the political entities. My supposition in this regard is that this kind of mistrust in other people and political bodies will be reflected on the level of trust in the political news that the youth get exposed to either from traditional media or new media. In addition, the interpersonal trust could lead to political cynicism: if people are not trusting each other or the political institutions. It is reflected on the public cynicism about politics.

RQ4: To what extent do youth trust in political news on Social Media?

Table 6: Degree of youth trust in political news on Social media

\begin{tabular}{|l|l|l|l|l|l|l|l|}
\hline Statement/phrase & $\begin{array}{l}\text { Strongly } \\
\text { Agree }\end{array}$ & Agree & $\begin{array}{l}\text { Neither } \\
\text { Agree } \\
\text { nor } \\
\text { Disagree }\end{array}$ & Disagree & $\begin{array}{l}\text { Strongly } \\
\text { Disagree }\end{array}$ & Mean & $\begin{array}{l}\text { Std. } \\
\text { Deviation }\end{array}$ \\
\hline $\begin{array}{l}\text { Most of the political } \\
\text { news circulating on } \\
\text { social media can be } \\
\text { trusted. }\end{array}$ & $1.3 \%$ & $12.4 \%$ & $40 \%$ & $38.7 \%$ & $7.6 \%$ & 2.61 & .849 \\
\hline $\begin{array}{l}\text { Be careful when I'm } \\
\text { exposed to } \\
\text { information about } \\
\text { political information } \\
\text { on social media. }\end{array}$ & $36 \%$ & $42.7 \%$ & $17.3 \%$ & $2.2 \%$ & $1.8 \%$ & 4.09 & .882 \\
\hline $\begin{array}{l}\text { I can only trust } \\
\text { political information } \\
\text { on social media if }\end{array}$ & $48.9 \%$ & $37.8 \%$ & $9.3 \%$ & $2.7 \%$ & $1.3 \%$ & 4.30 & .849 \\
\hline
\end{tabular}




\begin{tabular}{|c|c|c|c|c|c|c|c|}
\hline $\begin{array}{l}\text { there is evidence } \\
\text { from different } \\
\text { sources that confirms } \\
\text { its credibility. }\end{array}$ & & & & & & & \\
\hline $\begin{array}{l}\text { I consider social } \\
\text { media (Facebook, } \\
\text { Twitter) more reliable } \\
\text { as sources of news } \\
\text { and than } \\
\text { information political } \\
\text { traditional media } \\
\text { (television, } \\
\text { newspapers, radio). }\end{array}$ & $12 \%$ & $16 \%$ & $38.2 \%$ & $23.6 \%$ & $10.2 \%$ & 2.96 & 1.135 \\
\hline $\begin{array}{l}\text { I think the fake } \\
\text { political news on } \\
\text { social media has } \\
\text { increased } \\
\text { dramatically. }\end{array}$ & $29.8 \%$ & $43.1 \%$ & $21.3 \%$ & $4 \%$ & $1.8 \%$ & 3.95 & .912 \\
\hline $\begin{array}{l}\text { I feel that there are } \\
\text { political entities that } \\
\text { pay to promote } \\
\text { political news on } \\
\text { social media. }\end{array}$ & $31.6 \%$ & $30.7 \%$ & $24.9 \%$ & $9.8 \%$ & $3.1 \%$ & 3.78 & 1.092 \\
\hline
\end{tabular}

Source: Data are from the author's survey.

$\mathrm{N}=225$

Q: You have a set of phrases about news related to political topics via social media, please specify whether you agree or disagree with each statement.

The study highlights that young people are highly skeptic about the political news on social media. Surprisingly, they have less trust in social media though they expressed earlier that the social media became the main source of political information. Moreover, they have also less trust in traditional media as a source of political news.

The study confirms that respondents are worried about increasing political fake news (misinformation, disinformation, and malinformation) on social media which leads to further distrust in this news on social media. In addition, young citizens express their concerns about increasing political spin content on social media which contradicts media professionalism and decreases level of trust in political news published on social media.

This study is in agreement with the findings of some global studies indicate that the influence of trust on news consumption has been revealed to be pretty weak, and people frequently use news from 
sources they declare they do not trust (Tsfati and Cappella 2005). Moreover, researchers assume that trust in alternative media is - like general trust in media (Tsfati and Ariely, 2014) - correlated with respondents' political attitudes conditioned by the nation-state context.

This result raises the issue of the relationship between consumption and trusting news. People may need to consume news provided by different types of media although they are sometimes sceptic about its reliability and credibility. This argument needs to be further investigated in different social contexts to identify significant social, political, economic, communication, and personal factors that may affect people's level of trust in political news mainstreamed by either traditional or new media.

RQ5: To what extent do youth trust in political news in social media compared with traditional media?

Table 7: Degree of youth trust in political news on social media and traditional media

\begin{tabular}{|l|l|l|}
\hline Trust & Mean & Std. Deviation \\
\hline Traditional media (TV, newspapers, and radio). & 2.83 & 2.76 \\
\hline Social media (Facebook, Twitter). & 1.298 & 1.092 \\
\hline
\end{tabular}

Source: Data are from the author's survey.

$\mathrm{N}=225$

Q: How confident are you in political news on social media compared to traditional media, (1 means low confidence - 5 high confidence)

Surprisingly, respondents rate traditional media (Newspaper, Radio, and TV) more trustful than social media as a source of political news on this five-degree scale $(2.83,1.29$ respectively). This result is consistent with previous studies that have revealed that news consumption is correlated with trust of traditional news sources (Tsfati and Cappella 2003).

This study highlights that young people have a low level of trust in both media as the mean of the level of trust is lower than 3 on the five degrees scale. This result is aligned with other studies conducted in different social contexts. For example, long-term Gallup trend data document a decline in Americans' trust in the news media, with 41\% in 2017 saying 
they trust the media, down from 54\% in 2003. (Knight Foundation 2018).

RQ6: How much do youth politically engage by consuming political news on social media?

Table 8: Youth engagement based on social media political news consumption

\begin{tabular}{|l|c|c|}
\hline Type of interaction with political content & Mean & Std. Deviation \\
\hline Interaction with political content on Social Media & 2.11 & 1.106 \\
\hline
\end{tabular}

Source: Data are from the author's survey.

$\mathrm{N}=225$

Q: How much do you interact with the political materials that you see through social media? (1 means low interaction -5 means high interaction)

This study shows that respondents are not interacting with political news on social media (Mean: 2.11). This result confirms that young people might be consuming political news on social media, however, due to the less trust in the medium and content of this political news, they are not taken a step further in political engagement by liking or commenting or sharing this content. The study sheds light on the need for investigating social context and other factors that lead to trusting in political news on social media and participating in the public discourse or public sphere as a significant indicator for political participation.

The study finds that the Mean of interacting with political news on social media is tending to be low side on the five-degree scale. This result agrees with the above-mentioned results that show interacting with the political content on social media through the main three identified actions (share, comment, and like) is low.

\section{Table 9: Types of youth online engagement}

\begin{tabular}{|l|l|l|l|}
\hline Interactivity form & Always & Sometimes & Not \\
\hline Comment & $4.4 \%$ & $42.2 \%$ & $53.3 \%$ \\
\hline Share & $3.6 \%$ & $46.6 \%$ & $49.8 \%$ \\
\hline Like & $14.7 \%$ & $64.4 \%$ & $20.9 \%$ \\
\hline Other forms & $.4 \%$ & $4.4 \%$ & $95.2 \%$ \\
\hline
\end{tabular}

Source: Data are from the author's survey.

$\mathrm{N}=225$ 
Q: How much do you interact with the political content that you see on social media? (1 means low interaction - 5 means high interaction)

The study finds that the interacting method with political news on social media is mostly clicking by "Like" feature. Tow-third of engaged participants are doing this either always or sometimes. This confirms that engagement with the easiest action of interacting with some political news on social media. Although, "Like" as an indication for interaction, but it does not reflect the well and desire to disseminate and advocate this content and even make a solid (concrete) feedback on the content through submitting a "comment".

Table 10: Political deliberation by getting exposed to political news on social media

\begin{tabular}{|l|c|c|}
\hline Type of political interest & Mean & Std. Deviation \\
\hline Discuss with others news related to public affairs & 2.25 & 1.240 \\
\hline
\end{tabular}

Source: Data are from the author's survey.

$\mathrm{N}=225$

Q: Do you discuss with others about news related to political news that you experience on social media? (1 means low -5 means high)

The study shows that the Mean of deliberating about political news on social media with other young citizens is tending to the low side on the five-degree scale. This result is aligned with the above-mentioned results that show interacting with the political content on social media through the main three identified actions (share, comment and like) is low. It proves that the level of news trusting might be reflected on interacting with political news and discussing with others these raised political issues.

Table 11: Participate in public activities because of consuming political news on social media

\begin{tabular}{|l|l|l|}
\hline Type of offline political engagement & Mean & Std. Deviation \\
\hline Participate in any of the public activities & 2.84 & 1.259 \\
\hline
\end{tabular}

Source: Data are from the author's survey.

$\mathrm{N}=225$ 
Q: Do you participate in public activities such as volunteering, community participation, political events, elections based on the political information you obtain from social media? (1 means low -5 means high)

This result also highlights that among young people who answered that they are interacting with political news on social media, their engagement in real activities based on the political information that they gain from social media is below moderate (Mean $=2.84$; Std. Deviation: 1.259). These results confirm the above-mentioned results show that the political engagement of young citizens is low.

RQ7: Which variables affect youth trust in political news on social media?

An independent-samples t-test and one way between subjects (ANOVA) have been conducted to assess the effects of some sociodemographic factors (Gender, Age, Education, and Income) on respondents. These four variables were tested to identify the extent to which they affect the level of trusting in political news on social media, trusting in political news traditional media, and trusting in political news on social media and community participation among youth.

\section{Gender:}

There is a significant difference in the scores for males $(M=2.51$ $\mathrm{SD}=1.18)$ and females $(\mathrm{M}=3.00 \mathrm{SD}=1.32)$ in trusting political news in traditional media as females are more trusting, conditions; $\mathrm{t}(223)=-$ $2.7, \mathrm{p}=.007)$.

There is no significant difference between males $(\mathrm{M}=2.72 \mathrm{SD}=1.03)$ and females $(\mathrm{M}=2.78 \mathrm{SD}=1.12)$ in trusting political news on social media (Facebook and Twitter), conditions; $\mathrm{t}(223)=-.42, \mathrm{p}=.67$ )

There is no significant difference between males $(\mathrm{M}=2.72 \mathrm{SD}=1.25)$ and females $(\mathrm{M}=2.90 \mathrm{SD}=1.25)$ in trusting political news on social media and community participation, conditions; $\mathrm{t}(223)=-1.02, \mathrm{p}=.30)$.

Age:

There is a significant difference between 18-24 age group ( $M=2.86$ $\mathrm{SD}=1.30) \quad$ and $25-35$ age group $(\mathrm{M}=2.77 \quad \mathrm{SD}=1.28)$ in trusting 
political news in social media, as the youngest respondents have more trust, conditions $\mathrm{t}(223)=2.88, \mathrm{p}=.004)$.

There is no significant difference between 18-24 age group $(\mathrm{M}=2.89$ $\mathrm{SD}=1.08)$ and $25-35$ age group $(\mathrm{M}=2.44 \mathrm{SD}=1.04)$ in trusting political news in traditional media conditions $\mathrm{t}(223)=.43, \mathrm{p}=.66)$.

There is no significant difference between 18-24 age group (M=2.94 $\mathrm{SD}=1.28)$ and $25-35$ age group $(\mathrm{M}=2.59 \mathrm{SD}=1.17)$ in participating in community activities based on the political news received from social media conditions $\mathrm{t}(223)=1.88, \mathrm{p}=.06)$.

\section{Education level:}

There is no significant effect of education level on trusting political news in traditional media and participating in community activities based on the political information that they receive from social media at the $\mathrm{p}>.05$ level.

However, there is a significant effect of education level in trusting political news on social media (Facebook and Twitter) as the lower educational level groups are more trusting the political news in social media compared with the postgraduate level (Masters, Ph.Ds., and Diploma holders).

There is a significant effect of the education level on trusting the political news on social media at the $\mathrm{p}<.05$ level for the three conditions $[\mathrm{F}(2,222)=3.5, \mathrm{p}=0.03]$.

"Post hoc comparisons using the Tukey HSD test indicated that the mean scores the post-graduate certificate of condition $(\mathrm{M}=2.35, \mathrm{SD}=$ $1.05)$ is significantly different than the graduate certificate level condition $(\mathrm{M}=2.85, \mathrm{SD}=1.08)$. However, the secondary certificate (diploma) condition $(\mathrm{M}=2.86, \mathrm{SD}=1.09)$ does not significantly differ from the postgraduate certificate and graduate certificate level.

\section{Family Income level:}

There is no significant effect of the income level on trusting political news in traditional media, trusting political news on social media at the p>.05 level. 
However, there is a significant effect of the income level on participating in community activities based on the political news that they receive from social media (Seg. .02)

There is a significant effect of the income level on trusting political news on social media at the $\mathrm{p}<.05$ level for the three conditions $[\mathrm{F}(2$, $222)=3.79, \mathrm{p}=0.02]$.

"Post hoc comparisons using the Tukey HSD test indicates that the mean score for highest income condition $(\mathrm{M}=3.24, \mathrm{SD}=1.19)$ is significantly different than the moderate income condition $(\mathrm{M}=2.76$, $\mathrm{SD}=1.22)$ and low income condition $(\mathrm{M}=2.56, \mathrm{SD}=1.37)$. However, the moderate-income condition $(\mathrm{M}=2.76, \mathrm{SD}=1.22)$ does not significantly differ from the low-income condition $(\mathrm{M}=2.56, \mathrm{SD}=$ 1.37).

\section{Testing hypotheses:}

\section{Testing hypothesis 1}

H1: There will be a significant predication of trust in political news on social media by trust in traditional media, trust in government, trust in others, political engagement, gender, and the family economic status.

Multiple regression was carried out to investigate whether trust in traditional media, trust in government, trust in others, political engagement, gender, and the family economic status could significantly predict youth's level of trust in political news on social media. The results of the regression indicate that the model explained $16 \%$ of the variance and that the model was a significant predictor of trust in political news on social media, $\mathrm{F}(2,26)=9.34, \mathrm{p}=.001 \mathrm{~F}(8,218)=$ $6.59, \mathrm{p}=.000$.

Detailed results of the regression of all the six models indicated as follows:

M1: In this case, $R=0.2$, which is a week relationship. This suggests study model is not a relatively good predictor of the outcome. $\mathrm{R} 2=.04$, this value indicates the proportion of variation in the outcome variable (Trust in political news on social media) that can be explained by the model (i.e. Trust in Government). In this case, it is valid to say that $4 \%$ of the variance in the data can be explained by the predictor variables. 
The results indicated that the model was a significant predictor of trusting political news on social media, $\mathrm{F}(1,223)=9.99, \mathrm{p}=.002$.

M2: In this case, $\mathrm{R}=0.26$, which is a weak relationship. This suggests study model is not a relatively good predictor of the outcome. It indicates a positive correlation between the predictor variables and the outcome. R2=.07 this value indicates the proportion of variation in the outcome variable (Trust in Political News on Social Media) that can be explained by the model (i.e. Trust in Government and Gender). In this case, it is valid to say that $7 \%$ of the variance in the data can be explained by the predictor variables.

The results indicated that the model was a significant predictor of trusting political news on social media, $\mathrm{F}(2,222)=8.18, \mathrm{p}=.000$.

M3: In this case, $\mathrm{R}=0.32$, which is a weak relationship. This suggests our model is a relatively good predictor of the outcome. $\mathrm{R} 2=.1$, this value indicates the proportion of variation in the outcome variable (Trust in Political News on Social Media) that can be explained by the model (i.e. Trust in Government, Gender, and Trust in Traditional Media). In this case, it is valid to say that $10 \%$ of the variance in the data can be explained by the predictor variables.

The results indicated that the model was a significant predictor of trusting political news on social media, $\mathrm{F}(3,221)=8.38, \mathrm{p}=.000$.

M4: In this case, $\mathrm{R}=0.34$, which is a weak relationship. This suggests our model is a relatively good predictor of the outcome. $\mathrm{R} 2=.12$, this value indicates the proportion of variation in the outcome variable (Trust in Political News on Social Media) that can be explained by the model (i.e. Trust in Government, Gender, Trust in Traditional Media and Family economic status). In this case, it is valid to say that $12 \%$ of the variance in the data can be explained by the predictor variables.

The results indicated that the model was a significant predictor of trusting political news on Social Media, $F(4,220)=7.5, p=.000$.

M5: In this case, $\mathrm{R}=0.37$, which is a moderate relationship. This suggests our model is a relatively good predictor of the outcome. $\mathrm{R} 2=.14$, this value indicates the proportion of variation in the outcome variable (Trust in social media political news) that can be explained by the model (i.e. Trust in Government, Gender, Trust in Traditional 
Media, Income and Interaction with Political news on social media). In this case, it is valid to say that $14 \%$ of the variance in the data can be explained by the predictor variables.

The results indicated that the model was a significant predictor of trusting political news on social media, $\mathrm{F}(5,219)=7.01, \mathrm{p}=.000$.

M6: In this case, $\mathrm{R}=0.39$, which is a moderate relationship. This suggests our model is a relatively good predictor of the outcome. $\mathrm{R} 2=.16$, this value indicates the proportion of variation in the outcome variable (Trust in Political News on social media) that can be explained by the model (i.e. trust in government, gender, trust in traditional media, family economic status, and interaction with political news on social media and trust in others). In this case, it is valid to say that $16 \%$ of the variance in the data can be explained by the predictor variables.

The results indicated that the model was a significant predictor of trusting political news on social media, $F(8,218)=6.59, \mathrm{p}=.000$.

These above confirmed correlations do not refer to a causal connection between the two correlated variables, if there is a relationship it may be indirect.

\section{Testing hypothesis 2}

H2a: In the presence of others, there will be a significant prediction of trust in political news on social media by trust in traditional media.

Trust in traditional media significantly contributed to the model $(\mathrm{p}=.004)$

Trust in traditional media $(\mathrm{B} 1=-.501)$ as trust in traditional media increases by one unit (i.e. by one point), trust in political news on social media decreases by .501 points.

H2b: In the presence of others, there will be a significant prediction of trust in political news on social media by trust in government.

Trust in government significantly contributed to the model $(\mathrm{p}=.002)$

Trust in government $(\mathrm{B} 1=-.245)$ as trust in government increases by one unit (i.e. by one point), trust in political news on social media decreases by .245 points. 
H2c: In the presence of others, there will be a significant prediction of trust in political news on social media by trust in others.

Trust in others significantly contributed to the model $(\mathrm{p}=.04)$

Trust in others $(\mathrm{B} 1=.173)$ as trust in others increases by one unit (i.e. by one point), trust in political news on social media increases by .173 points.

H2d: In the presence of others, there will be a significant prediction of trust in political news on social media by online political engagement.

Interaction with political news on social media significantly contributed to the model $(\mathrm{p}=.03)$

Interaction with social media political news $(\mathrm{B} 1=.415)$ as interaction with social media political news increases by one unit (i.e. by one point), trust in political news on social media increases by .415 points.

H2e: In the presence of others, there will be a significant prediction of trust in political news on social media by gender.

Gender significantly contributed to the model $(\mathrm{p}=.003)$

Gender $(\mathrm{B} 1=.112)$ as female increases by one unit (i.e. by one point), trust in political news on social media increases by .112 points.

H2f: In the presence of others, there will be a significant prediction of trust in political news on social media by the family economic status.

Family economic status significantly contributed to the model $(\mathrm{p}=.03)$

Family economic status $(\mathrm{B} 1=-.714)$ as income increases by one unit (i.e. by one point), trust in political news on social media decreases by .714 points.

\section{CONCLUSION}

Using an online survey, this study investigates whether young people trust political news on social media, to what extent compared with traditional media, and which variables correlate to social media news trustfulness. In addition, it explores the impact of trust or distrust in these alternatives news sources and youth political engagement.

The study illustrates that youth show less interest in consuming political news in general as $46 \%$ said their interest is moderate, while $31 \%$ have 
less interest in political news, and only $23 \%$ said they have a high interest in following political issues. On sources of political information, almost half of the responses (49\%) confirmed that they rely on social media as the main source for gaining information about public issues. In this regard, findings point out that young people have less trust in general and lack of trust in the political institutes, specifically the government. They showed negative attitudes on all nine statements included in the scale of assess general and political trust.

The study highlights that the young people are highly sceptic about the political news on social media as they emphasize these negative attitudes on the six statements scale. Remarkably, they have less trust in social media though they expressed earlier that social media became the main source of political information. Moreover, they have also less trust in traditional media as a source of political news. Study confirms that young people are worried about increasing fake political news (misinformation disinformation and mal-information) in social media which leads to further distrust in this news platform. In addition, youth express their concerns about increasing political spin content on social media which contradicts media professionalism and decreases the level of trust in political news published on social media. Surprisingly, young citizens trusting traditional media as sources for political information more than social media with a Mean (2.83 versus 1.29$)$ on a five-degree scale.

Results of this study have been confirmed separate types of potentials linked with online media consumption and trust certainly. This result is consistent with other international findings showed that the influence of trust on online news usage is relatively weak. This means that people may need to consume news provided by different types of media although they are sometimes sceptic about its reliability. This argument needs to be further investigated in different social contexts to identify significant social, political, economic, communication, and personal factors that may affect people's level of trust in political news mainstreamed by either traditional or new media.

An independent-samples t-test and one way between subjects (ANOVA) have been conducted to assess the effects of some sociodemographic factors (Gender, Age, Education, and Income) on respondents' level of trusting social media as a political information 
source. These four variables were tested to identify the extent to which they are affecting the level of trusting in political news on social media, trusting in political news on traditional media, and trusting in political news on social media and political engagement among youth. Results point out that these variables alter level of trust in political news on social media as they are generally correlate with this dependent variable. It is assumed that trust in alternative media is - similar to general trust in media conditioned by the contextual specifics of the society.

Furthermore, multiple regression asserted that model variables trust in traditional media, trust in government, trust in others, political engagement, gender, and the family economic status could significantly predict youth's level of trust in political news on social media.

Also, results show that in the presence of others, there will be a significant predictor of trust in political news on social media by all model variables. (P value < 0.05 ). Result confirms that mistrust as an overall skepticism or suspicion around information that news audiences encounter on social media should be considered in the social, political, and economic contexts. Additionally, it shows that all kinds of trust are connected and if youth are distrustful or they have less trust in general, this might be reflected negatively on trust in social media as a political communication platform.

This study should be a part of longitudinal research of measuring trust in online political news, especially on social media. As citizens are widely turning to depend on the online media to get their political knowledge, there is a pressing need to evaluate ways of consuming news in social media and provide interpretations and recommendations on how society can capitalize use of social media to enhancing political engagement and social capital.

Giving the fact that the differences in selected predictors of media trust, samples, and the role national context plays, could the development of the varying pathways of media trust follows within these varied factors along socioeconomic and cultural lines. 
Results accentuate the importance of conducting further studies in different social contexts by using diverse instruments to provide sustainable updates to all stakeholders on: how people, especially young citizens, are consuming political news on social media, to what extent that youth trust social media as a source of political information, how this is affecting young citizens level of community engagement, and how could this practice to be improved as a part of building democracy. It is plausible to assume that declining political news credibility and increasing mistrust of political news online sources confirmed by this study might negatively impact the public discourse, social capital and, potentially harm democratic transition. These results shed a light on the need of improving the quality of online political news on social media as it seems to be a vital component of the virtual public sphere.

This study encountered some limitations including: First, the researcher selected a convenience voluntary sample that has been reached through social networking sites to fill out the questionnaires. Therefore, the selection biased must be put into consideration. Second, the respondents needed to have first a stable internet connection as it was the only means to reach and complete the questionnaire, while not everyone in Egypt has access to the internet just approximately (49\%) of the population (Internet World Stats, 2019). This percentage reflects major significant demographics differences, and it is subjecting the study findings to biases resulted from a non-coverage error. In addition to sampling error, the question wording can introduce error or bias into the findings of the survey. Furthermore, study could only adopt a broad perception of news trustfulness, while trust is a complex notion that could be disaggregated to sub elements (Engelke, Hase \& Winterlin, 2019). Accordingly, this study points out the need to further studies expanding the sample size to a random sample to achieve external validity. Moreover, conducting more content analysis on political news on social media to figure out more correlations for the purpose of enrich the literature for future research. 


\section{REFRENCES}

Alexa 2015. (2015). Retrieved April, 206, from https://www.alexa.com/

Avery, J.M. (2009). Videomalaise or virtuous circle? The influence of the news media on political trust. The International Journal of Press/Politics, 14(4), 410-433. doi: $10.1177 / 1940161209336224$

Barr A. (2003). Trust and expected trustworthiness: experimental evidence from Zimbabwean villages. Econ. J. 113, 614-630. 10.1111/1468-0297.t01-1-00150 [CrossRef] [Google Scholar]

Bauer, C. P. \& Freitag M. (2018). Measuring Trust. The Oxford Handbook of Social and Political Trust. Retrieved January 2019, from https://www.oxfordhandbooks.com/view/10.1093/oxfordhb/9780190274801.001.000 1/oxfordhb-9780190274801

Ben-Ner, A. \& Halldorsson, F. (2006). Measuring Trust: Which Measure Can Be Trusted? Retrieved June 15, 2019, from https://www.researchgate.net/publication/5100586_Measuring_Trust_Which_Measur e_Can_Be_Trusted

Boulianne, S. (2009). Does Internet use affect engagement? A meta-analysis of research. Political Communication, No. 26, iss. 2, p. 193-211.

Boulianne, S. (2011) Stimulating or reinforcing political interest: Using panel data to examine reciprocal effects between news media and political interest. Political Communication 28(2): 147-162.

Ceron, A. (2015). Internet, News, and Political Trust: The Difference Between Social Media and Online Media Outlets. Journal of Computer-Mediated Communication 20 (2015) 487-503: doi:10.1111/jcc4.12129

Clerwell, C. (2014). Enter the robot journalist: Users' perceptions of automated content, Journalism Practice, Vol. 8, No. 5 pp 519-531

Coleman, S., Anthony, S. \& Morrison, E.D. (2009). Public trust in the news: A constructivist study of the social life of the news, Oxford, Reuters Institute for the Study of Journalism. Retrieved March 2016, from: https://reutersinstitute.politics.ox.ac.uk/risjreview/public-trust-news-constructivist-study-social-life-news 10.1177/1609406915624574) doi: http://dx.doi.org/10.1177/0002764209331524

Dimitrova, D.V, Shehata, A., Strömbäck, J. \& Nord, L.W. (2011). The effects of digital media on political knowledge and participation in election campaigns: Evidence from panel data. Communication Research 2 November.

Digital Marketing Statistics \& Metrics. (2018). Social Media Users in Egypt: Twitter Insights and Usage in Egypt, 2018. Retrieved January, 2019, from https://www.digitalmarketingcommunity.com/indicators/twitter-insights-usage-inegypt-2018/

Dutton, W. H. (2009). "The Fifth Estate Emerging through the Network of Networks. Prometheus 27 (1): 1-15.

Edelman Trust Barometer .(2018). Global report. Retrieved December January, 2019, from https://www.edelman.com/trust-barometer 
Ellison, N. B., Steinfield, C., \& Lampe, C. (2007). The benefits of Facebook "friends:" Social capital and college students' use of online social network sites. Journal of ComputerMediated Communication, 12(4), 1143-1168. Retrieved June 2018, https://www.researchgate.net/publication/220438224_The_Benefits_of_Facebook_Fri ends_Social_Capital_and_College_Students'_Use_of_Online_Social_Network_Sites

Engelke, K. M., Hase, V., \& Wintterlin, F. (2019). On measuring trust and distrust in journalism: Reflection of the status quo and suggestions for the road ahead. Journal of Trust Research, 9(1), 66-86.

Eveland, W.P., Jr. (2004). The effect of political discussion in producing informed citizens: The roles of information, motivation, and elaboration. Political Communication, 21, 177193.

Eveland, W. P. Jr. \& Shah, Dhavan V. (2003). The impact of individual and interpersonal factors on perceived news media bias, Political Psychology, Vol. 24. No. 1 pp 101-117

Fehr, E., Fischbacher, U., Rosenbladt, B., Schupp, J., \& Wagner, G. (2002). “A nation-wide laboratory - Examining trust and trustworthiness by integrating behavioral experiments into representative surveys". Schmollers Jahrbuch 122, 519-543. https://www.iza.org/publications/dp/715/a-nation-wide-laboratory-examining-trustand-trustworthiness-by-integrating-behavioral-experiments-into-representativesurveys

Fisher, C., Park, S., Lee, J., Fuller, G., \& Sang, Y. (2019). Digital news report: Australia 2019. Canberra, Australia: News and Media Research Centre.

Flanagin, J.A. \& Metzger, J. M. (2007). The role of site features, user attributes, and information verification behaviors on the perceived credibility of Web-based information, New Media and Society, Vol. 9, No. 2 pp 319-342.

Fletcher, R. \& Nielsen, R.K. (2018). Are people incidentally exposed to news on social media. A comparative analysis. New Media \& Society, 20, 2450-2468.

Fletcher, R. \& Park, S. (2015). The Impact of Trust in the News Media on Online News Consumption and Participation. Retrieved from https://ora.ox.ac.uk/objects/unid:aec2681b-313e 42eb-9530 07e988e7b1ed/download_file?file_format=pdf\&safe_filename=Fletcher\%2Band\%2B Park \%252C\%2BThe\%2Bimpact\%2Bof\%2Btrust $\% 2$ Bin $\% 2$ Bthe $\% 2 \mathrm{Bnews} \% 2 \mathrm{Bmedia}$ $\%$ 2Bon\%2Bonline $\% 2$ Bnews $\% 2 \mathrm{~B}$ consumption $\% 2 \mathrm{Band} \% 2 \mathrm{Bparticipation.pdf \& type \_ o}$ f_work=Journal+article

Flintham,M., Karner, C., Creswick, H., Bachour, K. , Gupta, N., \& Moran, S. (2018). Falling for fake news: investigating the consumption of news via social media, In ACM CHI Conference on Human Factors in Computing Systems 2018. ACM CHI Conference on Human Factors in Computing Systems 2018. http://eprints:nottingham:ac:uk/49179/

Glaeser, L. E., Laibson, I. D., Scheinkman, A. J., \& Soutter L. C. (2000). Measuring Trust. The Quarterly Journal of Economics, 115, 3, 811-846.

Golan, Guy J. (2010) New perspectives on media credibility research, American Behavioral Scientist, Vol. 54, No. 1 pp 3-7.

Grabner- Kräuter, S. \& Bitter, S. (2015). Trust in online social networks: A multifaceted Perspective. Social Economics, 2015 Vol. 44, No. 1, 48-68. Retrieved July 3, from 
https://www.researchgate.net/publication/236010856_Trust_in_online_social_networ ks_A_multifaceted_perspective

Hardin, R. (2002). Trust and Trustworthiness. New York: Russell Sage.

Hargittal, E.\& SHAW, A. (2013). Digitally savvy citizenship: The role of Internet skills and engagement in young adults' political participation around the 2008 Presidential Election. Journal of Broadcasting \& Electronic Media, No. 57, iss. 2, p. 115-134.

Heuer, H. \& Breiter, A. (2018). Trust in News on Social Media. Retrieved December, 2018, from http://www.hen-drik.de/pub/nordichi2018.pdf

Holt, K.; Shehata, A.; Stromback, J., \& Ljungberg, E. (2013). Age and the effects of news media attention and social media use on political interest and participation: Do social media function as leveller? European Journal of Communication, No. 28, iss. 1, p. 19-34

https://doi.org/10.1145/3240167.3240172

Internet World Stats. (2019). Retrieved November 2019, from https://www.internetworldstats.com/stats1.htm

Im, T., Cho,W., Porumbescu, G.,\& Park, J. (2014). Internet, trust in government, and citizen compliance. Journal of Public Administration Research and Theory, 24(3), 741-763. doi:10.1093/jopart/mus037

Internet Users Statistics for https://www.digitalmarketingcommunity.com/indicators/twitter-insights-usage-inegypt-2018/)

Jakub Macek, Alena Macková1, Vassilis Pavlopoulos, Veronika Kalmus, C. Michael Elavsky, Johnson, J. T. \& Kaye, K. B. (1998). Cruising is believing? Comparing Internet and traditional sources on media credibility measures, Journalism and Mass Communication Quarterly, Vol. 75, No. 2 pp 325-340

Johnson, J., T. and Kaye, K.B. (2014) Credibility of social network sites for political information among politically interested Internet users, Journal of Computer-Mediated Communication, Vol. 19, No. 4 pp 957-974

Kaye, B.K., \& Johnson, T.J. (2002). Online and in the know: Uses and gratifications of the Web for political information. Journal of Broadcasting \& Electronic Media, 46(1): 54-71. doi:10.1207/s15506878jobem4601_4

Kiousis, S. (2009). Public Trust or Mistrust? Perceptions of Media Credibility in the Information Age. Mass Communication and Society 4 (4): 381-403

Knight Foundation. (2018). American views: Trust, media and democracy. doi: https://knightfoundation:org/reports/american-views-trust-media-and-democracy

Kohring, M. \& Matthes, J. (2007). Trust in news media: Development and validation of a multidimensional scale, Communication Research, Vol. 34, No. 2 pp 231-252

Kouisis, S. (2001.) Public trust or mistrust? Perceptions of media credibility in the information age, Mass Communication and Society, Vol. 4, No. 4 pp 381-403

Lee, Tien-Tsung (2010) Why they don't trust the media: An examination of factors predicting trust, American Behavioral Scientist, Vol. 54, No. 1 pp 8-21. 
Macek, J, Macková1, A., Pavlopoulos, V., Kalmus, V., Elavsky, C. M. \& Šerek. J. (2017). Trust in alternative and professional media: The case of the youth news audiences in three European countries). European Journal of Developmental Psychology. DOI: 10.1080/17405629.2017.1398079

Macková, A., Šerek, J., \& Macek J. (2017). Young People's Trust in Media: Between Mainstream and Alternative News Sources. At:1 st CATCH-EyoU Conference, Athens. DOI: 10.13140/RG.2.2.15368.42241.

Mayer, R. C., Davis, J. H., \& Schoorman, F. D. (1995). An integrative model of organizational trust. The Academy of Management Review, 20(3), 709-734.

McNeal, R., Hale, K., \& Dotterweich, L. (2008). Citizen-government interaction and the Internet: Expectations and accomplishments in contact, quality, and trust. Journal of Information Technology \& Politics, 5(2), 213-229. doi: 10.1080/19331680802298298

Milhorance, F. \& Singer, J. (2018). Media Trust and Use among Urban News Consumers in Brazil. Ethical Space: the international journal of communication ethics, 15(3/4), pp. 56-65. Retirived 4-2-2020, from https://openaccess.city.ac.uk/id/eprint/20565/1/2018EthicalSpaceMilhoranceSingerM ediaTrustBrazilCity.pdf

Newman, N., Fletcher, R., Kalogeropoulos, A., AL Levy, D., \& Nielsen, K. R. (2017). Reuters Institute Digital News Report 2017.doi: https://ssrn:com/abstract=3026082

Norris, P. (2000). A virtuous circle: Political communications in postindustrial societies. Cambridge, MA:Cambridge University Press.

Norris, P. (2011). Democratic deficit: Critical citizens revisited. NewYork, NY: Cambridge University Press.

Park, S., Fisher, C., Fuller, G., \& Lee, J. (2018). Digital news report: Australia 2018. Canberra, Australia: News \& Media Research Centre.

Pew Research Center. (2017). News Use Across Social Media Platforms 2017. (Sept. 2017). http://www:journalism:org/2017/09/07/news-use-across- social-media-platforms-2017

Pytlik Zillig, M. L. \& Kimbrough, D. C. (2015). Consensus on Conceptualizations and Definitions of Trust: Are We There Yet?. Retrieved 7-6-208, from https://www.researchgate.net/publication/278715728_Consensus_on_Conceptualizati ons_and_Definitions_of_Trust_Are_We_There_Yet

Rousseau, D. M., Sitkin, S. B., Burt, R. S., \& Camerer, C. (1998). Not so different after all: A cross-discipline view of trust. Academy of Management Review, 23(3), 393-404. doi: http://dx.doi.org/10.5465/AMR.1998.926617

Seckler, M. , Heinz, S. , Forde, S. , Touch, N. A. , \& Opwis, K. (2015). Trust and distrust on the web: User experiences and website characteristics. Computers in Human Behavior 45 (2015), 39-50.

Šrek, J. (2017). Trust in alternative and professional media: The case of the youth news audiences in three European countries). European Journal of Developmental Psychology. DOI: 10.1080/17405629.2017.1398079

Silverman, C. (2015). Lies, Damn Lies, and Viral Content: How News Websites Spread (and Debunk) Online Rumors, Unverified Claims, and Misinformation. Tow Centre for Digital Journalism, Columbia University. 
Snelson, L. C. (2016). Qualitative and Mixed Methods Social media Research: A Review of the Literature. International Journal of Qualitative Methods January-December 2016: $1-15$.

Statista: Social Media - Statistics \& Facts (2015). Retrieved June 2017, from https://www.statista.com/topics/1164/social-networks/

Sterrett, D., Malato, D.,Benz, J. ,Kantor, L,Tompson, T. ,Rosenstiel, T. ,Sonderman, J. \& Loker, K. (2019). Who Shared It?: Deciding What News to Trust on Social Media. Retrieved Jun, 2019, from https://doi.org/10.1080/21670811.2019.1623702

Stroud, N. J., Van Duyn, E., \& Peacock, C. (2016). News Commenters and News Comment Readers. Engaging News Project. http://engagingnewsproject.org/research/survey-ofcommenters-and-commentreaders

Suminas, A. \& Mierzecka, A. (2014). Political information sources for young citizens: a case study of Lithuanian youth information behavior. INFORMACIJOS MOKSLAI. 2014 70. Retrieved August 15, 2017, from file://C:/Users/hp1/Downloads/Politicalinformationsourcesforyoungcitizens\%20(1).p df

Sztompka, P. (1999). Trust: A Sociological Theory. Cambridge University Press, p. 55.

Thorson, K., Vraga, E. \& Brian Ekdale, B. (2010). Credibility in Context: How Uncivil Online Commentary Affects News Credibility." Mass Communication and Society 13 (3): 289-313.

Tsfati, Y. (2010). Online news exposure and trust in the mainstream media: Exploring possible associations. American Behavioral Scientist, 54(1), 22-42.

Tsfati, Y. \& Cappella, N. J. (2003). Do people watch what they do not trust? Exploring the association between news media scepticism and exposure, Communication Research, Vol. 30, No. 5 pp 504-529.

Tsfati, Y., \& Ariely, G. (2014). Individual and contextual correlates of trust in media across 44 countries. Communication Research, 41(6), 760-782.

Tsfati, Y., \& Cappella, N. J. (2005). Why Do People Watch News They Do Not Trust? The Need for Cognition as a Moderator in the Association between News Media Scepticism and Exposure." Media Psychology 7 (3): 251-271.

Vissers, S.\& Stolle, D. (2013). The Internet and new modes of political participation: online versus offline participation. Information, Communication \& Society, No. 17, iss. 8, p. 937-955.

Wang, Y. \& Mark, G. (2013). Trust in online news: comparing social media and official media use by Chinese citizens. Retrieved January, 2019, from https://dl.acm.org/doi/10.1145/2441776.2441843

Wanta, Wayne, \& Hu, Yu-Wei (1994) The effects of credibility, reliance, and exposure on media agenda-setting: A path analysis model, Journalism Quarterly, Vol. 71, No. 1 pp 90-98.

West, D. M. (1994). Validating a Scale for the Measurement of Credibility: A Covariance Structure Modeling Approach.” Journalism Quarterly 71 (1): 159-168. 
Westerman, D., Spence, R.P \& van der Heide, B. (2014) Social media as information source: Recency of updates and credibility of information, Journal of Computer-Mediated Communication, Vol. 19, No. 2 pp 171-183.

Wilson, S., Leong, P., Carmen Nge, C. \& Miang Hong, N. (2011). Trust and Credibility of Urban Youth on Online News Media. Malaysian Journal of Communication 27(2): 97 120. Retrieved October, 2018, from file:///C:/Users/hp1/Downloads/15090-41593-1SM.pdf 